\title{
TEXTS, TALK AND TECHNOLOGY: THE LITERACY PRACTICES OF BILINGUALLY-EDUCATED STUDENTS
}

\author{
TEXTOS, ORALIDADE E TECNOLOGIA: PRÁTICAS DE \\ LETRAMENTO DE ESTUDANTES EM CONTEXTO ESCOLAR \\ BILÍNGUE
}

\section{Paul Molyneux Renata Aliani}

\begin{abstract}
It is widely recognized that to be literate in today's world requires conscious, creative and critical deployment of language (and other semiotic devices) for different social purposes, contexts and audiences (FREEBODY \& LUKE, 1990, 2003). This notion of literacy as social practice (BARTON \& HAMILTON, 2000; STREET, 1995) has been extended to include the idea of multiliteracies (NEW LONDON GROUP, 1996; KALANTZIS \& COPE, 2012), in recognition of the roles technology and digital text use and production play in young people's lives. However, the literacy practices of primary school-aged students, as they enact them in their daily in-school and out-of-school lives, remain underinvestigated. This is particularly the case with bilingually-educated students whose literacy practices, involving texts, talk and technology, are deployed across languages. The research reported here investigated the literacy practices and language use of 68 students at three primary schools in Melbourne, Australia. Each of these schools offered bilingual programs to their students (involving instruction in Mandarin Chinese or Vietnamese, along with English). Data collected through individually administered questionnaires and small group interviews reveal these students live highly multilingual lives, where sophisticated linguistic choices and translanguaging are part of both their in-school and out-of-school lives. The research revealed that direct connections are made between the languages learned at school and personal, family and community literacy practices. As such, the students were found to attach high levels of importance to becoming biliterate, and powerfully attest to the linguistic, educational, social and functional benefits of bilingualism and a bilingual education. The research findings provide valuable insights into bilingual and multilingual practices involving texts, talk and technology. This article posits that bilingual education, as implemented at the three research sites, enhances students' learning and their sense of personal identity, as well as affording them skills and understandings they deploy in their own increasingly technology-mediated lives.
\end{abstract}

Keywords: bilingual students; literacy practices; multiliteracies.

\footnotetext{
* The University of Melbourne, Australia.pdmoly@unimelb.edu.au; The University of Melbourne, Australia.renata.aliani@unimelb.edu.au
} 


\section{RESUMO}

Ser letrado no mundo de hoje implica o uso consciente, criativo e crítico da linguagem (e outros recursos semióticos) para diferentes propósitos, contextos e públicos (FREEBODY \& LUKE, 1990, 2003). Essa noção de letramento como prática social (BARTON \& HAMILTON, 2000; STREET, 1995) foi ampliada a fim de incluir a ideia de multiletramentos (NEW LONDON GROUP, 1996; KALANTZIS \& COPE, 2012), em reconhecimento ao papel que a tecnologia e o texto digital exercem na vida dos jovens. Contudo, as práticas de letramento de estudantes do ensino primário, do modo como elas são vivenciadas dentro e fora da escola, ainda carecem ser mais investigadas. Este é o caso específico de alunos cujas práticas de letramentos, envolvendo textos, oralidade e tecnologia, são mobilizadas pelo cruzamento de linguagens. A pesquisa aqui relatada investigou as práticas de letramento e linguagem usada por 68 estudantes de três escolas primárias em Melbourne, Austrália. Cada uma dessas escolas oferecia programas bilíngues a seus alunos (envolvendo instrução em Mandarin ou Vietnamita, além de Inglês). Os dados foram coletados por meio de questionários e entrevistas com pequenos grupos e revelam que os alunos vivem experiências altamente multilíngues, nas quais escolhas linguísticas sofisticadas e o translingualismo integram suas vidas dentro e fora da escola. A pesquisa também relevou que ligações diretas são feitas entre as línguas/linguagens aprendidas na escola e as práticas de letramento pessoais, familiares e da comunidade. Assim sendo, os alunos atribuem um alto grau de importância ao fato de se tornarem biletrados e reconhecem os benefícios linguísticos, sociais, educacionais e funcionais de uma educação bilíngue. Os resultados do estudo fornecem ricas contribuições para as práticas bilíngues e multilíngues envolvendo textos, oralidade e tecnologia. Este artigo defende que a educação bilíngue, como foi implantada nos cenários investigados, potencializa a aprendizagem e o senso de identidade dos estudantes, ao mesmo tempo em que auxilia o desenvolvimento de habilidades e conhecimentos que esses estudantes mobilizam em suas vidas cada vez mais tecnologizadas.

Palavras-chave: estudantes bilíngues; práticas de letramento; multiletramentos.

\section{LITERATE LIVES IN THE CONTEMPORARY WORLD}

As the $21^{\text {st }}$ century loomed, great attention was devoted to attempting to conceptualise what society would look like in the near future. Scholars and academics, drawing on ethnographies of literate practice undertaken, in particular, by Heath (1983), Scribner and Cole (1981) and Street (1984), advanced the New Literacy Studies project whereby literacy was seen as intimately and inextricably linked to social purposes and cultural practices. This view of literacy was positioned as ideological (STREET, 1984; 1995) in the sense that issues of power, form and context meant that language and language use could no longer be seen as autonomous or benign. Studies of community literacy (HAMILTON, BARTON \& IVANIC, 1994; BARTON \& HAMILTON, 1998) illuminated the diverse practices that constitute literacy in different families, homes and in-school and out-of-school contexts. This more complex view of literacy, as both local and context-specific, was augmented by the rise of digital technologies and the identification of the literacy skills linked to 
new tools of information retrieval and interpersonal communication. Importantly, empowered literacy was seen as embracing skills and resources around text decoding, participation or meaning making, deployment or use and critical analysis (FREEBODY \& LUKE, 1990, 2003) and, in a similar framing, was conceptualized around operational, cultural and critical dimensions (GREEN, 1988; DURRANT \& GREEN, 2000).

A very different, post-millennial world, characterized by changing work practices, rapid advances in technology, different notions of citizenship, reconfigured service relationships, shifting and malleable identities and redefined learning cultures, was envisioned by the New London Group (1996). This group of academics and educationalists coined the term 'multiliteracies' as a response to what they believed were the multiple forms literate practice would take in both schools and society. While their identification of the multimodality of $21^{\text {st }}$ Century texts (as deploying a mix of linguistic, visual, spatial, audio, gestural and intertextual modes or devices) built on earlier notions of expanded literacy practice, it prompted renewed consideration of how 'being literate' might be reconceptualised and how school practices around the teaching of literacy might need to change. A more fulsome discussion of multiliteracies (COPE \& KALANTZIS, 2000) drew attention to literacy across languages with Lo Bianco (2000) in that volume commenting that

within a pedagogy of Multiliteracies, languages other than English, foreign languages, individual and societal bilingualism, and, more broadly, global language diversity justify their space. A Multiliteracies pedagogy cannot but be multilingual. (p. 105)

Since the first use of the term multiliteracies and the articulation of a facilitating pedagogy (NEW LONDON GROUP, 1996), much attention has been devoted to its recognition as a suitable framework to encompass contemporary learning and its deployment in school programs. Anstey and Bull (2006) have identified a multiliterate person as one who can interpret, use and produce electronic, live and paper texts that employ different semiotic systems for social, cultural, political, civic and economic purposes in socially and culturally diverse contexts. Other related research has focused on aspects of multiliterate practice such as visual literacy (ARIZPE \& STYLES, 2003; CALLOW, 1999, 2013); pedagogical approaches and classroom implementation (CLOONAN, 2012; JEWITT, 2008; UNSWORTH, 2002); children's and adolescents' digital practices in and out of school (MARSH, 2011; MILLS, 2010; BITTMAN, RUTHERFORD, BROWN \& UNSWORTH, 2011) and the complex literacies required to use or create online texts, particularly video/computer games (BEAVIS, 2007; BEAVIS, MUSPRATT 
\& THOMPSON, 2014; GEE, 2003). In essence, there is a realization that today's school-aged learners engage in sophisticated literate and learning practices in and out of the classroom, work creatively, collaboratively and critically in internet and other multimodal new media spaces, and use social media to continue their reading, writing and learning at any time, a phenomenon referred to as 'ubiquitous learning' (KALANTZIS \& COPE, 2012, p. 11).

In the fields of second language learning, applied linguistics and bilingual/ multilingual education, recent thinking has linked the ideas of multiliteracies, multilingualism, multimodal texts and the complexities of lived literate practice to the concepts of 'translanguaging' (BAKER, 2011; GARCIA \& LI WEI, 2014) and 'translingual practice' (CANAGARAJAH, 2013). Garcia (2009) refers to translanguaging as the "multiple discourse practices in which bilinguals engage to make sense of their bilingual worlds" (p. 45, her emphasis), which marks a shift from previous conceptualisations of bilingual practice that tended to separate or compartmentalize languages and language use. Likewise attempting to dismantle binary thinking (like mono/multi when considering language knowledge and use), Canagarajah (2013) suggests the term translingual practice better reflects dynamic language use and more accurately captures how "the semiotic resources in one's repertoire or in society interact more closely, become part of an integrated resource, and enhance each other" (p. 8).

Yet, while cultural and linguistic diversity is central to the multiliteracies project, and "new language practices" (GARCIA \& LI WEI, 2014, p. 21) underpin notions of translanguaging or translingual practice, studies centred on bilingual or bilingually-educated young people and their literacy practices across languages are rare. Without overlooking or in any way diminishing the rich, contextualized and family-based research undertaken in bilingual and multilingual contexts (see, for example, JESSEL, KENNER, GREGORY, RUBY \& ARJU, 2011; GREGORY \& WILLIAMS, 2000; MARTIN-JONES \& BHATT, 1998; MARTIN-JONES \& JONES, 2000; SAXENA, 2000), or the investigations of language use in culturally diverse and hybrid environments (PENNYCOOK, 2007; PENNYCOOK \& OTSUJI, 2015), school-aged children's textual practices and deployment of language resources - particularly amongst those children fortunate enough to receive a bilingual education - are under-researched. This is particularly the case in countries like Australia where, despite a highly multicultural and multilingual population, its institutions remain steadfastly monolingual. 


\section{LANGUAGES AND LITERACIES IN CONTEMPORARY AUSTRALIA}

As an immigrant society (only $3 \%$ of the population identify as Indigenous), Australia's current demography reflects the various waves of migration that have taken place since British colonisation of the continent in 1788. In the past 70 years in particular, Australia has come to possess new reserves of linguistic and cultural knowledge, as migrants from post-war Europe took up residence and citizenship, followed by more recent arrivals from the Asia-Pacific region, the Middle East and Africa. The most recent population census (AUSTRALIAN BUREAU OF STATISTICS, 2011) reveals that, while English is the dominant language in Australia, over 200 other languages are spoken daily in homes and workplaces, with about 61,000 people speaking an Indigenous language (see also NEW SOUTH WALES GOVERNMENT EDUCATION AND COMMUNITIES, 2013). It needs to be emphasised that, like Brazil, the depletion of Indigenous languages after colonisation has been catastrophic: of 1000 languages in Brazil a century ago, only 200 remain and of the 500 Australian languages at the point of initial British colonisation, it is predicted (KALANTZIS \& COPE, 2012, p. 24) that only a dozen will survive into the $21^{\text {st }}$ Century.

On a policy level, Australia's cultural and linguistic diversity was most prominently and positively foregrounded in the National Policy on Languages (LO BIANCO, 1987). This document provided guidelines for the nourishment of existing community language resources while articulating a template for a stronger emphasis on multilingualism in schools and society. The National Policy on Languages created the impetus for the establishment of bilingual and community language programs in schools, like those at the centerpiece of this research. Subsequent policy iterations (such as, COMMONWEALTH DEPARTMENT OF EMPLOYMENT EDUCATION AND TRAINING, 1991), while superficially acknowledging the multicultural, multilingual nature of Australia's population, took a steadfast attitude to the preeminence of English as the lingua franca of Australian schools and society. This trend was reinforced by the implementation of high stakes national testing in English (but no other languages) through the National Assessment Program - Literacy and Numeracy (NAPLAN) in 2008. This assessment program, with its attendant reporting and publication of school results, shifted the emphasis away from multilingualism and multiliteracies - to a very large degree. The pervasiveness of this 'monolingual mindset' has been noted and critiqued (CLYNE, 2005; HAJEK \& SLAUGHTER, 2015) with Clyne (1998) earlier commenting that Australia's history has been 
marked by tensions between monolingualism and multilingualism; monoculturalism and multiculturalism.

Despite this apparent retreat from policy level support for community languages and multilingualism over a thirty-year period, powerful initiatives that recognize existing students' linguistic resources (and build capacity in monolingual speakers) are taking place in some Australian schools. Amongst the most noteworthy of these, and the focus of the research reported here, are the schools with bilingual or dual language programs such as those in the Victorian Bilingual Schools network. These schools offer additive bilingual programs (LAMBERT, 1975; CUMMINS, 2000; MAY, 2014) so called because these programs aim to strengthen and develop both languages of instruction, enabling both to be incorporated into a student's existing linguistic repertoire. Additive bilingual programs are frequently contrasted with those described as subtractive or transitional (see BAKER 2011; CUMMINS 2000), which typically result in the loss of a student's first language as a dominant societal language is increasingly emphasised. For the research reported here, we selected schools offering bilingual programs as sites for investigation of the various affordances, outcomes and challenges experienced by the students, teachers and parents involved in their implementation. From a wider corpus of data, this article reports on the literacy practices of students involved in these programs. We were keen to investigate the ways in which the students were able to draw on multilingual resources afforded them by their involvement in bilingual programs. As such, the focus here is both on multiliteracies and multilingualism - that often overlooked element of being multiliterate.

\section{THIS STUDY AND ITS RESEARCH FOCUS}

This research was conducted in 2008-9 at three Australian primary schools where the students - many of whose first language was a language other than English - were given the opportunity to learn English alongside another language in bilingual education settings. To be defined by the Department of Education and Training (DE\&T) as a bilingual school in the state of Victoria, face-to-face teaching across at least two curriculum areas in the target language/s for at least 7.5 hours per week is required (DEPARTMENT OF EDUCATION AND TRAINING, 2015). Many schools decide to become bilingual schools in order to promote traditionally high status languages (like French or German) despite there not being significant numbers of speakers of these European languages in the Australian 
population. Other schools have selected languages that do reflect those spoken in the community (such as Mandarin Chinese, Vietnamese, Macedonian or Greek). The rationale behind these bilingual education programs has been to both honour language diversity per se, and to esteem and value community languages (many of them the languages of potentially vulnerable recently arrived immigrants or refugees who are making the difficult transition to a new country).

Only 12 government schools in Victoria currently offer bilingual learning opportunities (11 of them primary or elementary schools), and the three schools in this study were purposively invited to participate for two reasons. First, they were part of DE\&T's professional network of Victorian schools actively championing bilingualism and multilingualism in their programs. Second, the three schools catered largely for students from language backgrounds other than English. This meant that the bilingual programs at the schools drew on local community languages, as opposed to programs that focused on languages selected for the political, economic or symbolic status attached to those languages. Bilingual programs that teach local community languages (such as those spoken by immigrant and refugee background students) are more likely the targets for attack or critique from opponents of linguistic diversity and advocates of English only approaches to education, (see, for example, BARRY, 2001; PORTER, 1990; SCHLESINGER, 1991). Lo Bianco (2000) has observed that mastery of high status, essentially nonimmigrant languages has typically been seen as a skill that contributes positively to society,

however, when the languages are less foreign, when emotional attachment and mastery may be high, their study, public use, and maintenance 'threaten civilisation'. (p. 99)

Here, Lo Bianco (2000) critiques such deficit stances as reflecting fears that nourishment of community languages might lead to social fragmentation and ghettoized ethnic communities. Ill-informed as these perspectives on bilingual education in immigrant languages are, their arguments are often compelling on an emotional level and render these programs highly vulnerable to withdrawal of government funding. Subsequently, the imperative to research the outcomes of these programs and identify both the affordances and challenges experienced by participating students emerged as a major motivation for this study. This, added to the paucity of the research into bilingually educated students' language use, literacy practices, and their perceptions of this form of learning, justified the research focus. So, a key component of the research - which is the focus of this article - was the 
students' reported language use and enacted literacy practices across languages and across domains in and out of school.

The study posed the following research questions:

1. In what ways do students participating in bilingual education programs report: their language use and literacy practices (in and out-of-school, across and outside of the languages of instruction)?

2. their attitudes to learning in two languages (in terms of perceived benefits and challenges)?

3. How do students' reported participation and learning in bilingual education programs augment our understandings of what it means to engage in multiliterate or translingual practice?

\section{RESEARCH DESIGN AND METHODS}

A largely qualitative research design underpinned this study, though some quantification around survey responses reflect notions of mixed methods research (JOHNSON \& TURNER, 2003; MERTENS, 2003; MORSE, 2003; TASHAKKORI \& TEDDLIE, 1998; TEDDLIE \& TASHAKKORI, 2003). While the researchers' orientation to the participating school sites and students was largely qualitative, given our desire to enact a research design that allowed us to "study things in their natural settings, attempting to make sense of, or interpret, phenomena in terms of the meanings people bring to them" (DENZIN \& LINCOLN, 2000, p. 3), strategic, if limited, use of quantitative tools allowed for breadth (as well as depth) in terms of data collection and analysis.

So, given that qualitative research is inherently multi-method in focus (FLICK, 2002), some quantitative frames of analysis were included, reflecting the different data collection methods that were employed. In order to answer the central research questions, data were gathered in each participating school using the following methods:

- student questionnaires $(\mathrm{N}=68)$ investigating students' language use and language attitudes (especially in relation to the literacy practices students engaged in across languages); and

- student group interviews $(\mathrm{N}=5)$ with a total of 20 students to probe further the responses in their questionnaires. 
Interviews with key staff at each school (principal, bilingual program coordinators and teachers) provided contextual information about each school site. Once collected, data were analysed both quantitatively (in the form of percentages and tally counts), and qualitatively, wherein both questionnaires and interviews were coded according to emergent themes (MILES \& HUBERMAN, 1994; RICHARDS, 2005; SILVERMAN, 2006). This mix of quantitative and qualitative methods allowed for identification of both large scale trends in the data, as well as facilitating an understanding of more specific, personal perspectives around language use and literacy practice. As Teddlie and Tashakkori (2003) have remarked,

social phenomena cannot be fully understood using either purely qualitative or purely quantitative techniques. We need a variety of data sources and analyses to completely understand complex multifaceted institutions or realities. Mixed methods can provide that. (p. 16)

\section{RESEARCH SETTING AND PARTICIPANTS}

The three primary school sites were all of a similar demographic - classified by the DE\&T as comprising a medium to high number of families speaking languages other than English (LOTE) in the home, coupled with low socio-economic status. School enrolments varied from under 100 to nearly 200, and the bilingual programs were one of two Asian languages: Mandarin Chinese or Vietnamese. To varying degrees, these languages reflected those spoken in the communities local to each school. Each school offered an opt-in bilingual program, meaning these learning arrangements were open to all but not a compulsory feature of the school. At the time of this research, all bilingual programs began at the entry point to school (Year Prep), when children at the ages of 5 or 6 commence their primary school education, and continued to different year levels (reflecting staff logistics and funding at the school level). Each school's profile and its bilingual programs are summarised in Table 1 below.

Table 1. Research school sites

\begin{tabular}{|l|l|l|l|}
\hline & \multicolumn{1}{|c|}{ School A } & \multicolumn{1}{c|}{ School B } & \multicolumn{1}{c|}{ School C } \\
\hline Location & Inner city Melbourne & Inner city Melbourne & Inner city Melbourne \\
\hline $\begin{array}{l}\text { Total School } \\
\text { Enrolment }\end{array}$ & 160 students & 82 students & 177 students \\
\hline
\end{tabular}




\begin{tabular}{|l|l|l|l|}
\hline $\begin{array}{l}\text { Demographic } \\
\text { features of } \\
\text { school (DE\&T } \\
\text { rankings) }\end{array}$ & $\begin{array}{l}\text { (Medium-high LOTE; } \\
\text { low SES) }\end{array}$ & $\begin{array}{l}\text { (Medium-high LOTE; } \\
\text { low SES) }\end{array}$ & $\begin{array}{l}\text { (Medium-high } \\
\text { LOTE; low SES) }\end{array}$ \\
\hline $\begin{array}{l}\text { Number of bi- } \\
\text { lingual programs } \\
\text { and years of- } \\
\text { fered }\end{array}$ & $\begin{array}{l}\text { Two bilingual programs: } \\
\text { Y Years Prep-4 Manda- } \\
\text { rin-English } \\
\text { - Years Prep-2 Vietnam- } \\
\text { ese-English }\end{array}$ & $\begin{array}{l}\text { One bilingual pro- } \\
\text { gram: } \\
\text { - Years Prep-4 Man- } \\
\text { darin-English }\end{array}$ & $\begin{array}{l}\text { One bilingual pro- } \\
\text { gram: } \\
\text { - Years Prep-3 } \\
\text { Vietnamese-English } \\
\text { (Increasing each year } \\
\text {-aiming for Prep-6 } \\
\text { coverage) }\end{array}$ \\
\hline
\end{tabular}

Despite obvious similarities across the schools, each school's bilingual program had different organisational features that reflected local priorities and possibilities. These differentiated features across the schools were:

- School A undertook bilingual learning (in both the Mandarin-English and Vietnamese-English programs) in a first half of the week/second half of the week arrangement. This meant that students learnt in one language from Monday morning until Wednesday lunchtime, then in the other language from that afternoon until the end of school on Friday. Separate classrooms and different teachers allowed for focussed instruction in and through the target languages. In addition to the languages themselves, Mathematics and content linked to the classroom topic (involving Science, Social Studies concepts, etc.) were taught in each target language. Teachers working in the program planned collaboratively around which curriculum content would be specifically taught in each of the target languages. Collaborative planning and assessment were prioritised by the staff in the bilingual programs at this school.

- School B undertook a team teaching program whereby a Mandarin Chinese medium of instruction teacher worked with and English medium of instruction teacher in one classroom, grouping the students in different ways across the school day. The one group of students remained with these two teachers over the course of the school week. Mathematics was taught in Mandarin and content in terms of Integrated Studies was split evenly between the English and Mandarin classes. The class would be organised in flexible groupings to ensure focussed exposure to and use of the target languages of English and Mandarin.

- School C timetabled its bilingual program at different times across the week, 
with year level groups timetabled for $7+$ hours of Vietnamese instruction in various blocks of time from Monday to Friday. Within the Vietnamese program, the focus was on both learning Vietnamese and learning through Vietnamese. So instructional focuses would shift from reading to writing, to Mathematics, the classroom inquiry topic and to an explicit focus on the language itself.

In the case of some students at each school, the (non-English) language of instruction in the school's bilingual education program was the student's first language. For some students, English was the sole language of their home. In other cases, neither language of instruction was the student's principal language (their home language was another language not offered by the program). So, while a key rationale of the languages chosen for the bilingual programs in each of the three schools was closely linked to the languages spoken in the local communities, this did not mean the programs were only offered to students from those language backgrounds. At the time of this research, the three schools were known for their bilingual programs and some students were participating, having been enrolled by their parents, keen for their child to receive the benefits of a bilingual education.

After first receiving ethics approval from our university, followed by permission to conduct the research in the three schools from the DE\&T, recruitment of schools through their principals was undertaken. Plain language statements explaining the research were provided for the principals, teachers, parents and students at each school and signed consent forms were collected from those willing to be involved.

In line with Sonia Nieto's (1999) observation that those with the greatest stake in the decisions schools make are frequently the most silenced or overlooked, we wanted to foreground the voices and perspectives of the students themselves. At each of the three schools, the involvement of 20 bilingually educated students was hoped for and, thanks to both the support of the schools themselves and the willingness of the students (and their parents) to give their consent to participate, this goal was essentially achieved. At one school, in excess of this number of students participated, at another the number was slightly less, due to the smaller number of bilingually-educated students at the school. At the different schools, students recruited for the study were those who had completed a bilingual program at School $\mathrm{A}_{i}$ and those who, at the time of the research, were still participating in the bilingual programs in Schools B \& C. Initially, the research intention was to target the students who had fully completed the bilingual program on offer. However, only at School A was it possible to access and recruit sufficient numbers of these 
students. As a result, Schools B and C participants were drawn from those students currently experiencing bilingual learning. While this may be seen as a limitation of the study, it did allow for voices of students able to look back and reflect on their bilingual education experience, along with those speaking from direct and current experience.

Table 2 below highlights the characteristics of the participating students at the three sites. This information was gathered as part of the questionnaire data that began with asking students about themselves.

Table 2: student research participants

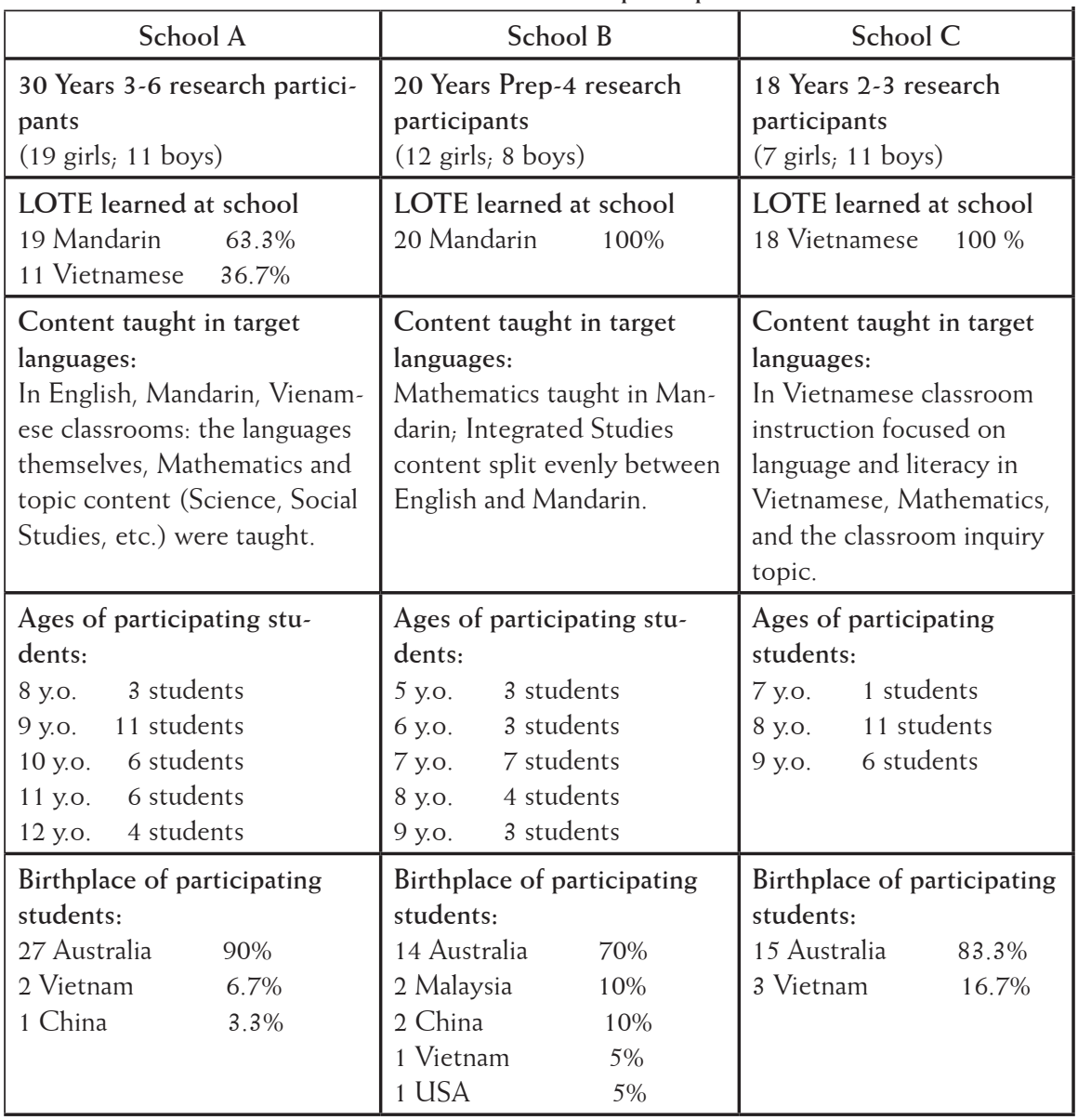




\begin{tabular}{|c|c|c|c|c|c|}
\hline \multicolumn{2}{|c|}{ Birthplace of mothers } & \multicolumn{2}{|c|}{ Birthplace of mothers } & \multicolumn{2}{|c|}{ Birthplace of mothers } \\
\hline $0 \quad$ Australia & $0 \%$ & $4 \quad$ Australia & $20 \%$ & 3 Australia & $16.7 \%$ \\
\hline 13 East Timor & $43.3 \%$ & 4 Malaysia & $20 \%$ & 14 Vietnam & $77.7 \%$ \\
\hline 13 Vietnam & $43.3 \%$ & 4 Vietnam & $20 \%$ & 1 Don't knou & $5.6 \%$ \\
\hline \multirow[t]{5}{*}{4 China } & $13.4 \%$ & 2 Brunei & $10 \%$ & & \\
\hline & & 2 USA & $10 \%$ & & \\
\hline & & 1 Canada & $5 \%$ & & \\
\hline & & 1 France & $5 \%$ & & \\
\hline & & 2 Don't know & $10 \%$ & & \\
\hline \multicolumn{2}{|c|}{ Birthplace of fathers } & \multicolumn{2}{|c|}{ Birthplace of fathers } & \multicolumn{2}{|c|}{ Birthplace of fathers } \\
\hline 1 Australia & $3.3 \%$ & 6 Australia & $30 \%$ & 4 Australia & $22.2 \%$ \\
\hline 10 East Timor & $33.3 \%$ & 4 Vietnam & $20 \%$ & 12 Vietnam & $66.7 \%$ \\
\hline 13 Vietnam & $43.3 \%$ & 3 Malaysia & $15 \%$ & 1 Holland & $5.6 \%$ \\
\hline 2 China & $6.7 \%$ & 2 Cambodia & $10 \%$ & 1 Singapore & $5.6 \%$ \\
\hline 2 Sri Lanka & $6.7 \%$ & 2 USA & $10 \%$ & & \\
\hline 1 Indonesia & $3.3 \%$ & 1 England & $5 \%$ & & \\
\hline \multirow[t]{2}{*}{1 Don't know } & $3.3 \%$ & 1 Singapore & $5 \%$ & & \\
\hline & & 1 Don't know & $5 \%$ & & \\
\hline
\end{tabular}

The key forms of data that relate to the focus of this article were a language use questionnaire and small group interviews. The language use questionnaire (see Appendix 1) had been developed in previous research (see MOLYNEUX, 2004, 2006a, 2006b, 2009) and was adapted for use in this study. The questionnaire, implemented dialogically and individually by the two researchers with each of the 68 participating students provided picture prompts depicting a range of in-school and out-of-school situations involving language and literacy practices which could be grouped under three broad categories as appear in Table 3 .

Table 3: language use questionnaire: literacy practices

\begin{tabular}{|c|c|c|}
\hline Literacy \& language use & Social use of language & Technology \& language use \\
\hline $\begin{array}{l}\text { Reading by yourself } \\
\text { Writing by yourself } \\
\text { Doing number work } \\
\text { Thinking about things } \\
\text { Listening to stories at home }\end{array}$ & $\begin{array}{l}\text { Talking with your parents } \\
\text { Talking with siblings } \\
\text { Talking with friends (in class } \\
\text { and out of school) } \\
\text { Buying things at the shops }\end{array}$ & $\begin{array}{l}\text { Computer use (writing, } \\
\text { playing games or visiting } \\
\text { websites) } \\
\text { Watching television (inc. } \\
\text { videos/DVDs) } \\
\text { Listening to music } \\
\text { Talking on the phone } \\
\text { Sending a text message }\end{array}$ \\
\hline
\end{tabular}

Using the pictures as prompts for their thinking, an elicitation device well supported as a useful support for research involving children or second language learners (NUNAN, 1992, JOHNSON \& WELLER, 2002), the students were asked 
to state the language or languages they used in these various everyday contexts or domains. They were not asked to quantify how much of each language they used as we believed this would be too difficult for them to calculate. In any case, it was the languages themselves (not the frequency of use) that we were wanting the students to identify. In this way, it was anticipated an understanding would emerge of students' literacy practices across languages (embracing those languages taught in school, as well as those in their family or personal repertoires).

After analysis of these questionnaire responses, students representing different patterns of language use (from largely monolingual to bi/multilingual across contexts or domains) were sought to participate in a group interview. A total of five student group interviews (comprising a total of 20 students - four students to a group) were conducted at the schools: two group interviews at Schools A and $\mathrm{C}$ and one group interview at School B (the school with the smallest enrolment). These group interviews were audio-taped for later transcription and ran for approximately 45 minutes. The primary objective of these interviews was to probe issues that emerged from the earlier-collected questionnaire data, allowing for more extended discussion of the lived experiences of students learning bilingually. The interviews asked students to discuss:

- their general feelings about learning in a bilingual program;

- what they found rewarding about learning bilingually or what it allowed them to do;

- what they found challenging about learning bilingually;

- whether they would have preferred to learn only in English;

- why they believed their school had made the decision to offer such instruction;

- suggestions about ways in which their bilingual learning might be improved.

As a result of both the language use questionnaire and the follow up group interviews, a complex picture emerged around the students' emerging bilingualism and of the school programs on offer. For the purposes of this article, the focus is on students' language use, literacy practices and perspectives on the affordances and challenges of learning bilingually. These research results are now discussed. 


\section{RESEARCH RESULTS: LANGUAGE USE QUESTIONNAIRE}

The language use questionnaire demonstrated that these 68 students, whose schooling emphasizes bilingualism, themselves live multilingual and multiliterate lives. For some, the schools' bilingual education opportunities mirror their existing home and community lives. For others, the bilingual education they receive allows them to participate in literate practice that might not otherwise be possible. This was evidenced by the high levels of bi/multilingual language use reported across a range of in-school and out-of-school contexts or domains. What follows is analysis of the students' reported literacy practices - across languages - as they relate to the three categories reflected in Table 3:

- those most associated with school-based literacies (reading, writing, number/ mathematics work, thinking and listening to stories),

- those that involve talk and social communication in class and out of school (with parents, siblings, friends and community members/shopkeepers), and

- those that involve technology (computer and television use, listening to music, as well as those related to telephone communication).

The data related to literate practice around technology are focussed on, in particular, given that these are most relevant for framings around $21^{\text {st }}$ Century literacies and being multiliterate.

The 68 language use questionnaire results were tallied for the 15 in-school and out-of-school domains or contexts in which the students reported single language use and use of two (or more) languages. Table 4, which follows, displays (in order of descending frequency) the percentage of students at each school that reported use of two or more languages in relation to the different domains or contexts pictured on the questionnaire. 
Table 4: domains of bilingual or multilingual literacy practice

\begin{tabular}{|ll|ll|ll|}
\hline \multicolumn{2}{|c|}{ School A } & \multicolumn{2}{c|}{ School B } & \multicolumn{2}{c|}{ School C } \\
\hline Watching TV/DVDs & $83.3 \%$ & Independent writing & $90 \%$ & Watching TV/DVDs & $77.8 \%$ \\
Talking on the phone & $80 \%$ & Independent reading & $75 \%$ & Listening to music & $66.6 \%$ \\
Independent writing & $80 \%$ & Watching TV/DVDs & $55 \%$ & Independent reading & $66.6 \%$ \\
Talking with friends & $73.3 \%$ & Talking on the phone & $55 \%$ & Independent writing & $66.6 \%$ \\
Computer use & $63.3 \%$ & Talking with friends & $55 \%$ & Computer use & $66.6 \%$ \\
Independent reading & $60 \%$ & Talking with parents & $50 \%$ & Shopping & $55.6 \%$ \\
Talking with parents & $53.3 \%$ & Doing number work & $50 \%$ & Talking on the phone & $50 \%$ \\
Listening to music & $53.3 \%$ & Computer use & $50 \%$ & Doing number work & $50 \%$ \\
Shopping & $50 \%$ & Listening to music & $40 \%$ & Talking with siblings & $50 \%$ \\
Talking with siblings & $43.3 \%$ & Shopping & $30 \%$ & Thinking about things & $44.4 \%$ \\
Doing number work & $43.3 \%$ & Talking with siblings & $30 \%$ & Talking with friends & $38.9 \%$ \\
Thinking about things & $33.3 \%$ & Listening to stories & $15 \%$ & Talking with parents & $33.3 \%$ \\
Dreaming in sleep & $26.7 \%$ & Thinking about things & $20 \%$ & Dreaming in sleep & $33.3 \%$ \\
Listening to stories & $13.3 \%$ & Dreaming in sleep & $15 \%$ & Listening to stories & $16.7 \%$ \\
Sending a text message & $10 \%$ & Sending a text message & $10 \%$ & Sending a text message & $0 \%$ \\
\hline
\end{tabular}

Students at each of the three schools reported high levels of bilingual practice around their independent reading and writing, with slightly less reported use of two (or more) languages for number work or mathematical computation. Listening to stories at home was not a common practice amongst the students in any language (depending on the school, from one-quarter to nearly one half of students reported they did not participate in this practice at home at all). The high incidences of reading and writing reported in two or more languages are unsurprising given the instructional practices of the schools which foreground the bilingual teaching of reading and writing. The reported bilingual textual practices around independent reading and writing nonetheless reveals the take-up of the learning on offer and the personal use made of this. It is important to note that, while School A had - by far - the greatest number of parents not born in Australia (only one parent of the 30 participating students), the levels of bilingual or multilingual practice reported by these students were not markedly different to those levels reported in Schools $\mathrm{B}$ and $\mathrm{C}$ (with their higher number of Australian-born parents). This indicates that the bilingual education offered in the three schools was the overriding catalyst for the students' use of more than one language.

The students' social use of language - their talk - highlights the ways that bilingual or multilingual ability is reflected in interactional practices. Except at School C, higher levels of bilingual communication were reported amongst friendship groups than with siblings. What this would appear to indicate - though further research is needed - is the way in-class talk in the two languages extends into social out-of-class talk. Intergeneration talk patterns and language shift is an area 
of great interest (see CLYNE, 2001; FISHMAN, 2001) and, while not the central focus of this study, the children's reporting of communication with their parents is noteworthy. At Schools A and B, as can be seen in Table 4, over half the students report communicating with their parents in more than one language. At School $\mathrm{C}$, the number was only one-third of students surveyed. However, the number of students who reported communicating with their parents in a language other than English only was considerable: at School A, 14 of the 30 students reported such communication practices and the numbers at the other two schools were likewise moderate to high ( 5 out of 20 at School B and 8 out of 18 at School C). Whether the talk with friends, parents or siblings was monolingual or multilingual, what clearly emerges from the data here is that languages other than English play a vital role in communication within and outside families. In other words, the linguistic spillover from the bilingual programs to the children's lives is formidable, reflecting the relevance and importance of the programs to the enacted language and literacy practices of the students.

With regards to technology, the questionnaire results showed that very high numbers of students used English and another language or languages for the majority of these practices. This was consistent across the three schools in terms of computer use, television viewing, listening to music (with the exception of School B) and talking on the telephone. When it came to sending a text message, however, English seemed to be the language most used by students, though the large majority of students surveyed did not report texting at all (perhaps unsurprising given the young ages of many or most of them). If this study were conducted now, it is likely the students' responses might reflect the proliferation of iPads and other hand-held digital devices that even these few years ago were not as prevalent in classrooms or in homes. To highlight the consistent use of English and another (or other) languages across the identified areas of technology use, Table 5 follows. This provides numbers and percentages of students utilizing two or more languages to enact literacy practices associated with technology and newer forms of literate practice.

Table 5: technology and language use

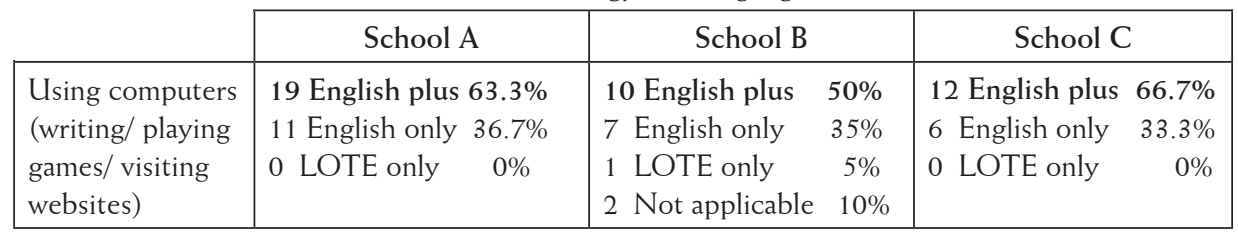




\begin{tabular}{|c|c|c|c|}
\hline $\begin{array}{l}\text { Watching televi- } \\
\text { sion (inc. video/ } \\
\text { DVDs) }\end{array}$ & $\begin{array}{ll}25 \text { English plus } & 83.3 \% \\
5 & \text { English only } \\
16.7 \% \\
0 \text { LOTE only } & 0 \%\end{array}$ & $\begin{array}{llc}11 & \text { English plus } & 55 \% \\
9 & \text { English only } & 45 \% \\
0 & \text { LOTE only } & 0 \%\end{array}$ & $\begin{array}{lr}14 \text { English plus } & 77.8 \% \\
4 \text { English only } & 22.2 \% \\
0 \text { LOTE only } & 0 \%\end{array}$ \\
\hline $\begin{array}{l}\text { Listening to } \\
\text { music }\end{array}$ & $\begin{array}{ll}16 \text { English plus } & 53.3 \% \\
12 \text { English only } & 40 \% \\
2 \text { LOTE only } & 6.7 \%\end{array}$ & \begin{tabular}{|lc}
8 English plus & $40 \%$ \\
10 English only & $50 \%$ \\
1 LOTE only & $5 \%$ \\
1 Not applicable & $5 \%$
\end{tabular} & $\begin{array}{lr}12 \text { English plus } & 66.7 \% \\
6 \text { English only } & 33.3 \% \\
0 \text { LOTE only } & 0 \%\end{array}$ \\
\hline $\begin{array}{l}\text { Talking on the } \\
\text { phone }\end{array}$ & $\begin{array}{lr}24 \text { English plus } & 80 \% \\
2 \text { English only } & 6.7 \% \\
4 \text { LOTE only } & 13.3 \%\end{array}$ & $\begin{array}{llc}11 & \text { English plus } & 55 \% \\
8 & \text { English only } & 40 \% \\
1 & \text { LOTE only } & 5 \%\end{array}$ & $\begin{array}{llr}9 & \text { English plus } & 50 \% \\
6 & \text { English only } & 33.3 \% \\
3 & \text { LOTE only } & 16.7 \%\end{array}$ \\
\hline $\begin{array}{l}\text { Sending a text } \\
\text { message }\end{array}$ & $\begin{array}{lr}\text { 3 English plus } & \mathbf{1 0} \% \\
13 \text { English only } & 43.3 \% \\
0 \text { LOTE only } & 0 \% \\
\text { 14 Not applicable } & 46.7 \%\end{array}$ & \begin{tabular}{|llr}
2 & English plus & $10 \%$ \\
2 & English only & $10 \%$ \\
0 & LOTE only & $0 \%$ \\
16 & Not applicable & $80 \%$
\end{tabular} & $\begin{array}{lr}\text { 0 English plus } & \mathbf{0} \% \\
\text { 8 English only } & 44.4 \% \\
\text { 1 LOTE only } & 5.6 \% \\
\text { 9 Not applicable } & 50 \%\end{array}$ \\
\hline
\end{tabular}

\section{INTERVIEW INSIGHTS}

A strong sense of feeling special and being proud of successful learning in two languages characterized the responses of students in the small group interviews. It needs to be noted how willing the students were to talk about their learning. In fact, it is not overstating the case to note that the students relished the opportunity to reflect and comment on their learning. Such observations around the student data collection process reinforce the need for teachers and researchers to actively seek student insights into their learning and the practices of schools.

From the questionnaires, it was found that all but one of the 68 students thought it was a good idea that their school offered a bilingual program. The small group interviews allowed for this overwhelmingly positive perspective to be probed. What was evident in these convivial and considered interviews was that students saw real relevance to their current and future lives in learning bilingually, even though they acknowledged the challenges (and occasional frustrations) in learning two languages at school. Interview transcripts were coded and what emerged strongly were themes of the linguistic, educational, social and functional benefits the students attached to bilingual learning. They were consistently able to provide examples of ways in which they currently drew on these skills in their enacted literacy practices and were likewise able to project into the future to articulate how they envisioned these skills might be deployed in the future. Many students commented on the overall benefits of being proficient in a second language, one student suggested that, through bilingual learning: 
You can get to learn to speak another language and it is good for people to have a second language. (Year 3 student, male, School C).

Some students commented on how bilingualism expanded their social and communicative opportunities, as the following quote indicates:

I get to understand the teacher and friends and mum and dad and lots of people. (Year 3 student, female, at School A).

Another student at the same school commented, when she speaks Chinese in the local community, people are often surprised that a non-Asian person communicates effectively in Mandarin:

If you talk to people who've never met you, they look at you and you don't look Asian or something and then you start talking their language and they look really surprised and they ask you how many languages you speak and you say 2 or 3 and they're really surprised. (Year 5 student, female, at School A)

The emotional significance of becoming proficient in a language linked to the family featured in several students' responses. Intergenerational communication and cohesion, along with maintenance of a cultural heritage, emerge as concerns in much bilingual research (MOLYNEUX, 2009; SHIN, 2000; YOUNG \& TRAN, 1999) and these were reflected in student comments across the three schools, such as:

My Mum doesn't want me to forget Vietnamese because she's scared I might forget the culture. She's scared I might forget it. (Year 3 student, male, at School C).

When I was in kindergarten when I go to my grandma's house I didn't understand Chinese, I didn't understand what she said because she knows Mandarin and I didn't understand until I got to bilingual school I learnt what she said. (Year 4 student, female, School B).

Because, like, if an auntie or an uncle from another country comes over to Australia, or if they talk to you over the phone, you can talk your home language. (Year 5 student, female, School A).

In terms of currently employed literacy practices, the students commented on how bilingual proficiency created confidence and expanded opportunities and associated benefits in school, in the home and in the community. For example:

If you learn another language you can get extra marks for the test when you go to high school and university. (Year 5 student, male, School A)

I mostly just speak English with my family, but sometimes I speak Chinese. And I can speak what I want when I get older. (Year 2 student, male, School B)

When I go shopping with my parents, I can speak to the shopkeeper in Vietnamese. (Year 6 student, female, School A). 
Other students, drawing on cultural knowledge gained at school and/or in the home, looked into the future to hypothesise some of the affordances being bilingual might bring. One student stated:

My Mum says in China there's lots of languages, but everyone has to know Mandarin, so I could talk to every person in China." (Year 3 Student, female, School B),

Another student commented on the intercultural benefits bilingual learning offered, particularly in regards to Australia as a multicultural, multilingual society:

It helps us understand different cultures of English and Chinese. How they are different, like writing the date: they put the year first in Chinese, but in English, they put the date first. It's the opposite way. (Year 5 student, male, School A)

While too young to avail themselves of the full range of opportunities around digital technologies and digital literacy (in particular related to social networks and other forms of online communication), the students in this study were very much focused on the role computer use plays in their lives and in their potential learning. When asked to reflect on how their bilingual learning could be improved, many students recommended an increased focus on online tools, interactive technologies and games. One student commented:

We could change some of the subjects to make it different, not like boring not just keep learning and learning because we are kids we should have fun. The teacher could go on the internet to get sites and we could build things. (Year 3/4 student, male, School A).

Throughout the interviews, students remarked on the challenges - as well as the rewards - of learning two languages. Particularly for those students whose home language was not Mandarin or Vietnamese, learning in those languages posed particular challenges. One student commented:

For some people, Vietnamese can be a bit confusing." [Prompt: Who?] "People that don't have Vietnamese background. (Year 2 student, female, School C).

Another student remarked on the cognitive demands that bilingual learning placed on the learner:

You might not have enough room in your brain to put everything in. (Year 2 student, female, School B). 
Ultimately, what emerged from the student research data, both the questionnaires and the small group interviews, was a sense of possibility and promise offered by being literate in more than one language. Even if a student did not have a family connection to the non-English language being taught, there was a sense that a new world had opened by being involved in bilingual education. One young student participant, when asked what was good about learning Vietnamese, commented:

Well, it's like stretching my brain a bit and that will help me learn some more languages after I have learned a bit more Vietnamese. (Year 2 student, male, School C).

\section{IMPLICATIONS OF THE STUDY}

This article began with a discussion of what it means to be literate, or multiliterate, in today's world. It was noted that multilingualism, while identified as an inherent feature of being multiliterate (NEW LONDON GROUP, 1996), has often been an overlooked component of that pedagogy, especially in societies where majority language concerns have dominated. Despite some attention (at times considerable) to notions of cultural and linguistic diversity in multicultural, multilingual countries like Australia, and in spite of very helpful frameworks around translanguaging (BAKER, 2011; GARCIA, 2009; GARCIA \& LI WEI, 2014) and translingual practice (CANAGARAJAH, 2013), understanding of young people's multiliterate or translingual practice is lacking. And, because of this, schools' awareness of and responses to their students' highly complex and sophisticated literacy lifeworlds is all too often insufficient.

Our understanding of what it means to be multiliterate or translingual especially in the context of the lives of primary school students - has been augmented by this research. Across a range of domains in and out of school, the students in this study recounted - with considerable pride - their deployment of their emerging bilingual skill set. A picture emerges here of students strategically drawing on their ability in the languages of their school instruction when communicating with siblings, friends, family and community members, when engaging in reading and writing practices in and out of school, and when engaging with technology. While the study relied on self-reported language use - the research aimed not to undertake a finegrained discursive analysis of their speech or writing - the participating students' accounts give substance to Canagarajah's (2013) identification of translingualism as demonstration of an individual's ability to use their language(s) successfully in specific contexts and for identified purposes. 
This study revealed that students deeply appreciate the opportunity to learn in bilingual programs. Regardless of their language backgrounds, an understanding and appreciation of how bilingualism expands one's social and communicative opportunities characterized the student data. Students who had some family connection to Mandarin or Vietnamese made direct reference to the emotional significance of becoming proficient in a language so deeply related to the home and identity. Norton (2000) remarks that one's sense of identity is continually being constructed and re-negotiated as a result of interactions with others, and as mediated by a range of institutions such as families, schools, and workplaces. Schools like the three in this study that support bilingual learning endow multilingualism with power and capital that enhances the identity and self-worth of all learners, but particularly those students whose cultural and linguistic knowledge can be so easily overlooked.

The results of this study highlight that when children are supported by quality, additive bilingual teaching that affirms their linguistic and cultural knowledge while explicitly supporting their language and literacy needs, this can be reflected in their enacted literacy practices around texts, talk and technology. While the students in this study themselves acknowledged the learning demands this places on them (both on those from both English-speaking backgrounds and those from other language backgrounds), their feelings of pride and "being special" in terms of their learning and their enhanced abilities more than compensated. These three schools' bilingual programs have indeed survived and thrived in the years after this research, and proudly foreground their language programs on their school websites. Bilingual education programs, it appears, are starting to receive the attention they warrant as the community takes heed of their existence, their outcomes, and new research into neuro-science (for example, in media reports such as SILVER \& MALCOLM, 2012; PROCTOR, 2014). Ultimately however, bilingual education - an uncommon pedagogical arrangement in Victoria - still warrants wider consideration as a method for supporting to develop both the essential development of English language and literacy as well as maximising the linguistic potential our students bring to primary school classrooms.

\section{REFERENCES}

ANSTEY, M., \& BULL, G. (2006). Teaching and learning multiliteracies: Changing times, changing literacies. Kensington Gardens, SA: Australian Literacy Educators' Association.

ARIZPE, E., \& STYLES, M. (2003). Children reading pictures: Interpreting visual texts. London: Routledge Falmer. 
AUSTRALIAN BUREAU OF STATISTICS. (2011). Census of population and housing. Retrieved from http://www.abs.gov.au/websitedbs/censushome.nsf/home/ census? opendocument\&navpos $=10$

BAKER, C. (2011). Foundations of bilingual education and bilingualism (5th ed.). Bristol, UK: Multilingual Matters.

BARTON, D., \& HAMILTON, M. (1998). Local literacies: Reading and writing in one community. London: Routledge.

BARTON, D., \& HAMILTON, M. (2000). Literacy practices. In D. Barton, M. Hamilton, \& R. Ivanic (Eds.), Situated literacies: Reading and writing in context (pp. 7-15). London: Routledge.

BARRY, B. (2001). Culture and equality: An egalitarian critique of multiculturalism. Cambridge, UK: Polity Press.

BEAVIS, C. (2007). New Textual Worlds: Young people and computer games. In N. Dolby and F. Rizvi Youth Moves: Identities in Global Perspective, Routledge pp.53-65.

BEAVIS, C., MUSPRATT, S. \& THOMPSON, R. (2014) 'Computer games can get your brain working': student experience and perception of digital games in the classroom. Learning Media and Technology, 40 (1), 1-22.

BITTMAN, M., RUTHERFORD, L., BROWN, J., \& UNSWORTH, L. (2011). Digital natives? New and old media and children's outcomes. Australian Journal of Education, 55(2), 161-175.

CALLOW, J. (Ed.) (1999). Image matters: Visual texts in the classroom. Newtown, NSW: Primary English Teaching Association.

CALLOW, J. (2013). The shape of text to come: How image and text work. Newtown, NSW: Primary English Teaching Association of Australia (PETAA).

CANAGARAJAH, S. (2013). Translingual practice: Global Englishes and cosmopolitan relations. London: Routledge.

CLOONAN, A. (2012). Multimodal literacies: new approaches and traditional concerns in the suburban classroom. In R. Henderson (Ed.). Teaching literacies in the middle years: Pedagogies and diversity. (pp. 166-189). South Melbourne: Oxford University Press.

CLYNE, M. (1998). Managing language diversity and second language programmes in Australia. In S. Wright \& H. Kelly-Holmes (Eds.), Managing language diversity (pp. 429). Clevedon, UK: Multilingual Matters.

CLYNE, M. (2001). Can the shift from immigrant languages be reversed in Australia? In J. A. Fishman (Ed.), Can tbreatened languages be saved? Reversing language shift, revisited: A 21st century perspective (pp. 364-390). Clevedon, UK: Multilingual Matters.

CLYNE, M. (2005). Australia's Language Potential. Sydney: University of New South Wales Press. 
COMMONWEALTH DEPARTMENT OF EMPLOYMENT EDUCATION AND TRAINING. (1991). Australia's language: The Australian language and literacy policy. Canberra: Australian Government Printing Service.

COPE, B., \& KALANTZIS, M. (Eds.). (2000). Multiliteracies: Literacy learning and the design of social futures. South Yarra, Vic: Macmillan.

CUMMINS, J. (2000). Language, power and pedagogy: Bilingual children in the crossfire. Clevedon, UK: Multilingual Matters.

DENZIN, N. K., \& LINCOLN, Y. S. (2000). The discipline and practice of qualitative research. In N. K. Denzin \& Y. S. Lincoln (Eds.), Handbook of qualitative research (2nd ed., pp. 1-28). Thousand Oaks, CA: Sage Publications.

DEPARTMENT OF EDUCATION AND TRAINING. (2015). Languages Provision in Victorian Government Schools, 2014. Melbourne: Department of Education and Training.

DURRANT, C., \& GREEN, B. (2000). Literacy and the new technologies in school education: Meeting the 1(IT)eracy challenge? Australian Journal of Language and Literacy, 23(2), 87-108.

FISHMAN, J. A. (Ed.) (2001). Can threatened languages be saved? Reversing language shift, revisited: A 21 st century perspective. Clevedon, UK: Multilingual Matters.

FLICK, U. (2002). An introduction to qualitative research: Theory, method and application (2nd ed.). Thousand Oaks, CA: Sage Publications.

FREEBODY, P., \& LUKE, A. (1990). 'Literacies' programs: Debates and demands in cultural context. Prospect, 5, 7 - 16.

FREEBODY, P., \& LUKE, A. (2003). Literacy as engaging with new forms of life: The four roles model. In M. Anstey \& G. Bull (Eds.), The literacy lexicon (pp. 51 - 65). French's Forest, NSW: Pearson.

GARCIA, O. (2009). Bilingual education in the 21st century: A global perspective. Alden, MA: Wiley-Blackwell.

GARCIA, O., \& LI WEI. (2014). Translanguaging: Language, bilingualism and education. New York: Palgrave Macmillan.

GEE, J. P. (2003). What video games bave to teach us about learning and literacy. New York: Palgrave Macmillan.

GREGORY, E., \& WILLIAMS, A. (2000). City literacies: Learning to read across generations and cultures. London: Routledge.

GREEN, B. (1988) Subject-specific literacy and school learning: A focus on writing. Australian Journal of Education, 32 (2), 156-179.

HAJEK, J., \& SLAUGHTER, Y. (Eds.). (2015). Challenging the monolingual mindset. Bristol: Multilingual Matters.

HAMILTON, M., BARTON, D., \& IVANIC, R. (Eds.). (1994). Worlds of literacy. Clevedon, UK: Multilingual Matters.

HEATH, S. B. (1983). Ways with words: Language, life, and work in communities and classrooms. Cambridge: Cambridge University Press. 
JESSEL, J., KENNER, C., GREGORY, E., RUBY, M. \& ARJU, T. (2011). Different spaces: Learning and literacy with children and their grandparents in east London homes. Linguistics and Education, 22(1), pp. 37-50.

JEWITT, C. (2008). Multimodality and literacy in school classrooms. Review of Research in Education, 32, 241-267.

JOHNSON, B., \& TURNER, L. A. (2003). Data collection strategies in mixed methods research. In A. Tashakkori \& C. Teddlie (Eds.), Handbook of mixed methods in social and behavioral research (pp. 297-319). Thousand Oaks, CA: Sage Publications.

JOHNSON, J. C., \& WELLER, S. C. (2002). Elicitation techniques for interviewing. In J. F. Gubrium \& J. A. Holstein (Eds.), Handbook of interview research: Context and method (pp. 491 - 514). Thousand Oaks, CA: Sage Publications.

KALANTZIS, M., \& COPE, B. (2012). Literacies. Port Melbourne: Cambridge University Press.

LAMBERT, W. E. (1975). Culture and language as factors in learning and education. In A. Wolfgang (Ed.), Education of immigrant students (pp. 55 - 83). Toronto: Ontario Institute for Studies in Education.

LO BIANCO, J. (1987). National policy on languages. Canberra: Australian Government Publishing Service.

LO BIANCO, J. (2000). Multiliteracies and multilingualism. In B. Cope \& M. Kalantzis (Eds.), Multiliteracies: Literacy learning and the design of social futures (pp. 92-105). South Yarra: Macmillan.

MALCOLM, L., \& SILVER, K. (2012, 21st October). The bilingual brain. All in the mind. Retrieved from http://www.abc.net.au/radionational/programs/allinthemind/the-blingual-brain $/ 4315620$

MARSH, J. (2011). Young children's literacy practices in a virtual world: Establishing an online interaction order. Reading Research Quarterly, 46(2), pp. 101-118.

MARTIN-JONES, M., \& BHATT, A. (1998). Literacies in the lives of young Gujarati speakers in Leicester. In A. Y. Durgunoglu \& L. Verhoeven (Eds.), Literacy development in a multilingual context: Cross-cultural perspectives (pp. 37-50). Mahwah, NJ: Lawrence Erlbaum Associates.

MARTIN-JONES, M., \& JONES, K. (Eds.). (2000). Multilingual literacies: Reading and writing different worlds. Amsterdam: John Benjamins.

MAY, S. (Ed.) (2014). The multilingual turn: Implications for SLA, TESOL and bilingual education. New York: Routledge.

MERTENS, D. M. (2003). Mixed methods and the politics of human research: The transformative-emancipatory perspective. In A. Tashakkori \& C. Teddlie (Eds.), Handbook of mixed methods in social and bebavioral research (pp. 135-164). Thousand Oaks, CA: Sage Publications.

MILES, M. B., \& HUBERMAN, A. M. (1994). Qualitative data analysis: An expanded sourcebook (2nd ed.). Thousand Oaks, CA: Sage Publications. 
MILLS, K. (2010). Shrek meets Vygotsky: Rethinking adolescents' multimodal literacy practices in schools. Journal of Adolescent and Adult Literacy, 54(1), 35-45.

MOLYNEUX, P. (2004). Pride and empowerment: Bilingually educated students reflect on their learning. Australian Language and Literacy Matters, 1(2), 4-10.

MOLYNEUX, P. (2006a). Transportable literacies and transformative pedagogies: An investigation of the tensions and choices in the provision of education for bilingualism and biliteracy. (PhD), University of Melbourne, Melbourne.

MOLYNEUX, P. (2006b). The Importance of a Theory-Informed Understanding of Additive Bilingual Education. Babel, 41(2), pp. 18-22, 35 \& 38.

MOLYNEUX, P. (2009). Education for biliteracy: Maximising the linguistic potential of diverse learners in Australia's primary schools. Australian Journal of Language and Literacy, $32(2), 97-117$.

MORSE, J. M. (2003). Principles of mixed methods and multimethod research designs. In A. Tashakkori \& C. Teddlie (Eds.), Handbook of mixed methods in social and behavioral research (pp. 189-208). Thousand Oaks, CA: Sage Publications.

NEW LONDON GROUP. (1996). A pedagogy of multiliteracies: Designing social futures. Harvard Educational Review, 66(1), pp. 60-92.

NEW SOUTH WALES GOVERNMENT EDUCATION AND COMMUNITIES. (2013). Racism no way: Anti-racism education for Australian schools. Retrieved from http://www.racismnoway.com.au/about-racism/population/

NIETO, S. (1999). Critical multicultural education and students' perspectives. In S. May (Ed.), Critical multiculturalism: Rethinking multicultural and antiracist education (pp. 191-215). London: Falmer Press.

NORTON, B. (2000). Identity and language learning: Gender, ethnicity and educational change. London: Longman.

NUNAN, D. (1992). Research methods in language learning. Cambridge: Cambridge University Press.

PENNYCOOK, A. (2007). Global Englishes and Transcultural Flows. London: Routledge.

PENNYCOOK, A., \& OTSUJI, E. (2015). Metrolingualism: Language in the city. New York: Routledge.

PORTER, R. P. (1990). Forked tongue: The politics of bilingual education. New York: Basic Books.

PROCTOR, J. (2014, September 15). Achtung baby: The future is bi-lingual preps. The Age. Retrieved from http://www.theage.com.au/national/education/achtung-babythe-future-is-bilingual-preps-20140901-10axsc.html

RICHARDS, L. (2005). Handling research data: A practical guide. Thousand Oaks, CA: Sage Publications.

SAXENA, M. (2000). Taking account of history and culture in community-based research on multilingual literacy. In M. Martin-Jones \& K. Jones (Eds.), Multilingual literacies: Reading and writing different worlds (pp. 275-298). Amsterdam: John Benjamins. 
SCHLESINGER, A. J. (1991). The disuniting of America: reflections on a multicultural society. New York: W.W. Norton.

SCRIBNER, S., \& COLE, M. (1981). The psychology of literacy. Cambridge, MA: Harvard University Press.

SHIN, F. H. (2000). Parent attitudes toward the principles of bilingual education and their children's participation in bilingual programs. Journal of Intercultural Studies, 21(1), 9399.

SILVERMAN, D. (2006). Interpreting qualitative data: Methods for analysing talk, text and interaction (3rd ed.). Thousand Oaks, CA: Sage Publications.

STREET, B. V. (1984). Literacy in theory and practice. New York: Cambridge University Press.

STREET, B. V. (1995). Social literacies: Critical approaches to literacy in development, ethnography and education. London: Longman.

TASHAKKORI, A., \& TEDDLIE, C. (1998). Mixed methodology: Combining qualitative and quantitative approaches. Thousand Oaks, CA: Sage Publications.

TEDDLIE, C., \& TASHAKKORI, A. (2003). Major issues and controversies in the use of mixed methods in the social and behavioral sciences. In A. Tashakkori \& C. Teddlie (Eds.), Handbook of mixed methods in social and behavioral research (pp. 3-50). Thousand Oaks, CA: Sage Publications.

UNSWORTH, L. (2002). Changing dimensions of school literacies. Australian Journal of Language and Literacy, 25(1), pp. 62-77.

YOUNG, R. L., \& TRAN, M. L. T. (1999). Vietnamese parent attitudes toward bilingual education. Bilingual Research Journal, 23(2/3), pp. 225-233. 


\section{APPENDIX 1: STUDENT QUESTIONNAIRE}

\section{STUDENT QUESTIONNAIRE}

In this section we ask students to provide information about the language or languages they use for diferent activities.

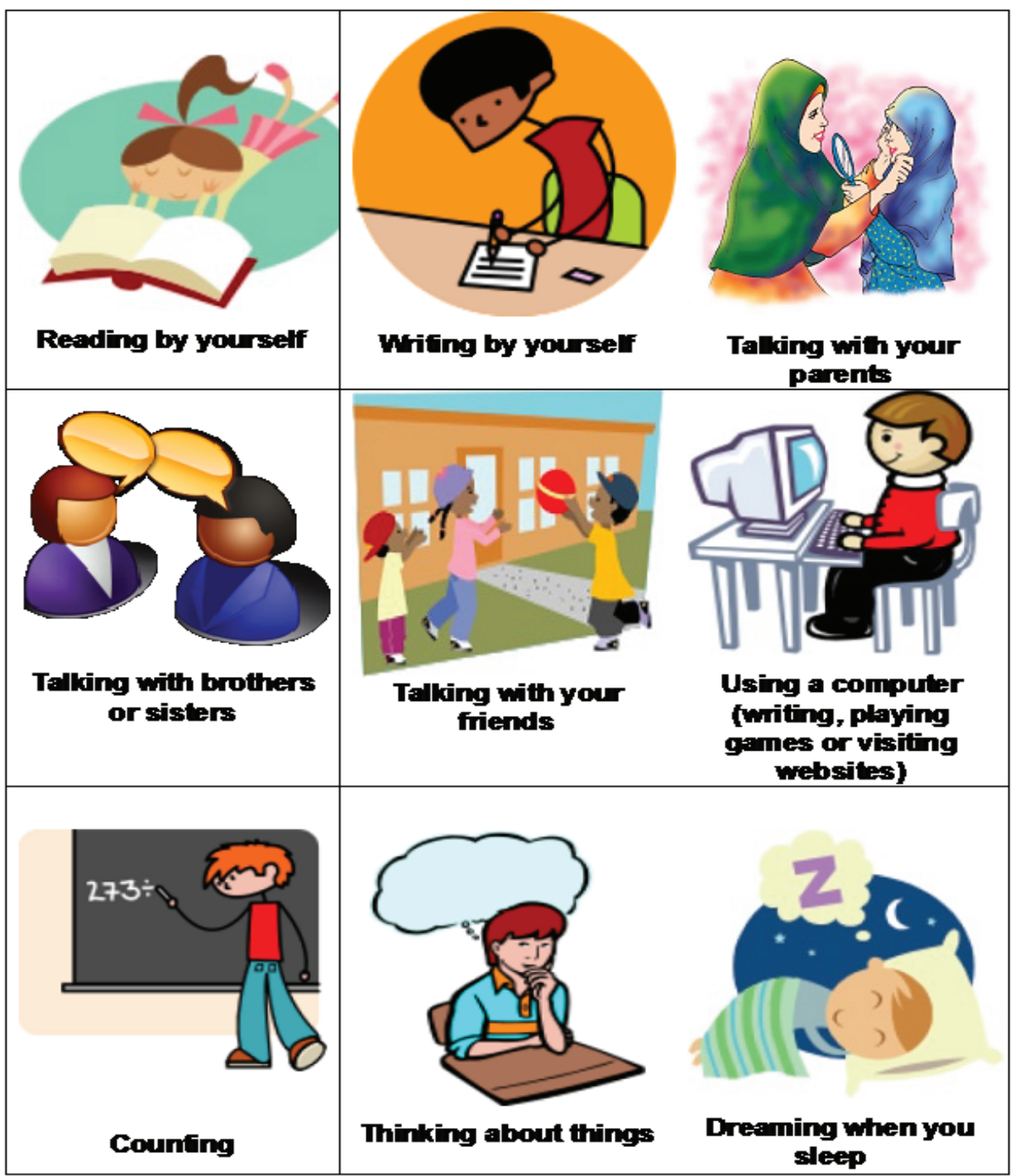




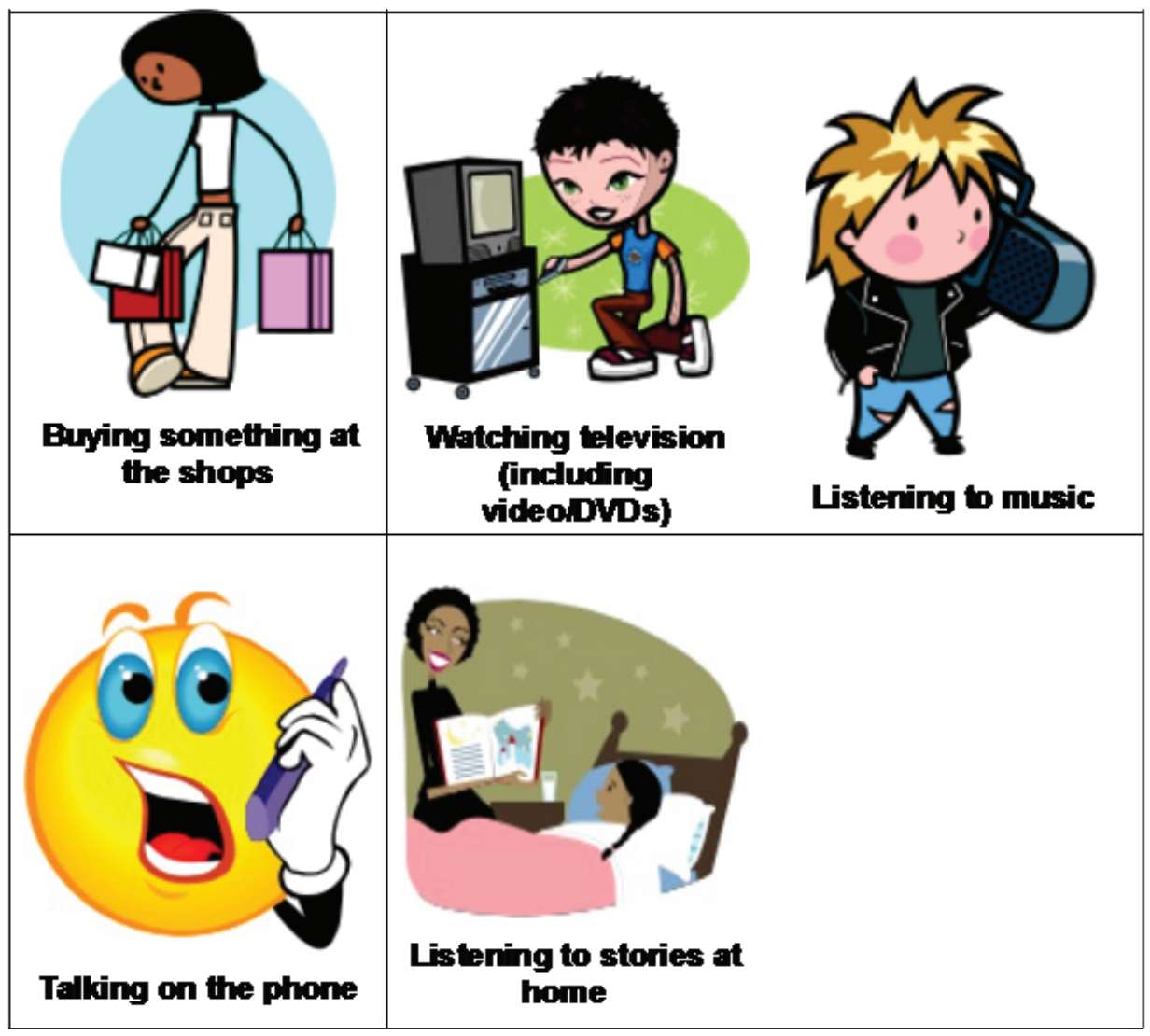

Recebido: 31/01/2016

Aceito: 05/07/2016 